\title{
Analisis Residu Pestisida dalam Tomat, Cabai Rawit dan Wortel dari Beberapa Pasar Tradisional di Sulawesi Utara
}

\author{
Abdon Saiya ${ }^{a *}$, Dokri Gumolunga, Joice Dorsila Susana Caroles ${ }^{a}$ \\ a Jurusan Kimia, Fakultas MIPA, Universitas Negeri Manado, Tondano, 95618, Indonesia
}

INFO ARTIKEL

Diterima 16 Oktober 2018

Disetujui 30 Oktober 2018

\section{Keywords:}

chlorpyrifos,

hplc,

tomato,

Cayenne pepper,

carrot

\section{Kata kunci:}

klorpirifos,

hplc,

tomat,

cabai rawit,

wortel

${ }^{*}$ e-mail:

abdonsaiya@unima.ac.id

${ }^{*}$ Telp: 085240868530

\begin{abstract}
A B STRACT
One method to eradicate plant pests carried out by farmers in the North Sulawesi area is to use pesticides because they are considered easy to obtain, the price is still affordable, and very effective at killing plant pests. However, improper use of pesticides results in the loss of pesticide residues in plants which causes environmental pollution, health problems in humans and inhibits trade. Therefore, it is necessary to monitor the use of pesticides through the fulfillment of the maximum residual limit (BMR). This study aims to analyze pesticide residues in tomatoes, cayenne pepper, and carrots using the method of High Performance Liquid Chromatography (HPLC) which was previously optimized and validated. The research samples were tomatoes, cayenne pepper, and carrots, taken from Pasar Bersehati Tomohon, Pasar Karombasan Manado, and Pasar Kawangkoan Minahasa, then taken to the Chemistry Laboratory of Manado State University to be extracted and analyzed. The results of this study indicate that pesticides with chlorpyrifos active ingredients were detected in almost all samples analyzed, although the levels were still below the specified BMR value, ie $1 \mathrm{mg} / \mathrm{kg}$ sample. The highest chlorpyrifos level was found in tomato samples taken from Pasar Kawangkoan Minahasa, which was $0.3150 \mathrm{mg} / \mathrm{kg}$. The results of this study also showed that samples that were washed before extraction caused a decrease in the residual content of the petisides.
\end{abstract}

\section{A B STRAK}

Salah satu cara memberantas hama tanaman yang dilakukan oleh para petani di daerah Sulawesi Utara adalah menggunakan pestisida karena dianggap mudah didapat, harganya masih bisa dijangkau, dan sangat efektif membunuh hama tanaman. Namun, penggunaan pestisida yang tidak tepat mengakibatkan tertinggalnya residu pestisida tersebut pada tanaman sehingga menyebabkan pencemaran lingkungan, gangguan kesehatan pada manusia dan menghambat perdagangan. Oleh karena itu, perlu dilakukan pengawasan terhadap penggunaan pestisida melalui pemenuhan nilai batas maksimum residu (BMR). Penelitian ini bertujuan untuk menganalisis residu pestisida dalam tomat, cabai rawit, dan wortel dengan metode High Performance Liquid Chromatography (HPLC) yang telah dioptimasi dan divalidasi sebelumnya. Sampel penelitian berupa tomat, cabai rawit, dan wortel, diambil dari Pasar Tomohon, Pasar Karombasan, dan Pasar Kawangkoan, kemudian dibawa ke laboratorium Kimia Universitas Negeri Manado untuk diekstraksi dan dianalisis. Hasil penelitian ini menunjukkan bahwa pestisida dengan bahan aktif klorpirifos terdeteksi hampir pada semua sampel yang dianalisis, walaupun kadarnya masih berada di bawah nilai BMR yang ditetapkan, yaitu $1 \mathrm{mg} / \mathrm{kg}$ sampel. Kadar klorpirifos tertinggi dijumpai pada sampel tomat yang diambil dari Pasar Kawangkoan, yakni 0,3150 $\mathrm{mg} / \mathrm{kg}$ sampel. Hasil penelitian ini juga menunjukkan bahwa sampel yang dicuci terlebih dahulu sebelum diekstraksi menyebabkan terjadinya penurunan kadar residu petisidanya.

Kata kunci: klorpirifos, hplc, tomat, cabai rawit, wortel 


\section{PENDAHULUAN}

Berdasarkan hasil survey yang kami lakukan terhadap beberapa petani yang ada di daerah Sulawesi Utara, umumnya mereka memberantas hama tanaman dengan menggunakan pestisida karena mudah didapat, harganya relatif masih dapat dijangkau, dan sangat efektif membunuh hama tanaman [1]. Padahal penggunaan pestisida secara tidak tepat dapat meninggalkan residu pestisida tersebut pada tanaman yang dapat menyebabkan pencemaran lingkungan, gangguan kesehatan pada manusia, serta dapat menghambat perdagangan [2]. Oleh karena itu, perlu dilakukan pengawasan terhadap penggunaan pestisida melalui pemenuhan nilai batas maksimum residu (BMR) sehingga dapat menjamin keamanan pangan dengan cara membatasi kadar residu pestisida pada komoditas hasil-hasil pertanian.

Salah satu jenis pestisida yang banyak digunakan petani adalah pestisida golongan organofosfat dengan bahan aktif klorpirifos. Hal ini disebabkan karena pestisida golongan organofosfat memiliki karakteristik yang lebih menguntungkan dibandingkan dengan pestisida organoklorin, seperti mudah terurai dan waktu persistennya yang singkat [2]. Pestisida organofosfat melindungi tanaman dari hama dengan menghambat aktivitas enzim asetilkolineterase pada serangga. Penggunaannya dengan cara disemprot pada tanaman atau tanah, menyebabkan residunya dapat ditemukan di permukaan air tanah, buahbuahan, sayuran dan air minum [3].

Penelitian yang kami lakukan sebelumnya menunjukkan bahwa pestisida dengan bahan aktif klorpirifos terdeteksi pada semua sampel sayur kubis yang diambil dari beberapa pasar tradisional di Sulawesi Utara, walaupun kadarnya masih di bawah nilai BMR yang ditetapkan[1]. Keberadaan pestisida organofosfat dengan bahan aktif klorpirifos dalam produk-produk pertanian juga telah dilaporkan oleh beberapa peneliti di Indonesia. Panggabean [4] dalam penelitiannya tentang analisis residu klorpirifos dalam sayur-sayuran dengan teknik HPLC, menemukan adanya residu klorpirifos dalam sampel sayur kubis yang dianalisis dengan kadar 0,131 \pm 0,008 $\mu \mathrm{g} / \mathrm{kg}$. Kadar tersebut masih jauh di bawah nilai BMR yang ditetapkan untuk klorpirifos dalam sayur kubis, yaitu 1 mg/kg (SNI 7313:2008). Marzuki dkk., juga menemukan adanya residu klorpirifos pada sampel uji Sawi Hijau di Kabupaten Gowa, walaupun masih dalam ambang toleransi BMR [5]. Berdasarkan hasil penelitian Triani dkk., ratarata residu pestisida klorpirifos pada kacang panjang di Kecamatan Baturiti Kecamatan Marga dan Kecamatan Kerambitan masing-masing sebesar 0,0397 mg/kg, 0,0169 mg/kg, dan 0,0118 $\mathrm{mg} / \mathrm{kg}$, hasil tersebut masih di bawah BMR, sedangkan dikecamatan Penebel sebesar 0,2447 $\mathrm{mg} / \mathrm{kg}$ masih berada di atas BMR [6]

Berdasarkan hasil penelusuran literatur maupun pengamatan di lapangan yang kami lakukan sejauh ini, masih sangat kurang penelitian yang dilakukan untuk analisis residu pestisida pada hasil-hasil pertanian di daerah Sulawesi Utara. Oleh karena itu, penelitian ini dilakukan dengan tujuan untuk menentukan kadar residu klorpirifos dalam sampel tomat, cabai rawit, dan wortel diambil dari beberapa pasar tradisional yang ada di Sulwesi Utara menggunakan metode HPLC yang telah dioptimasi dan divalidasi sebelumnya [7].

\section{Bahan dan Metode}

Peralatan yang digunakan dalam penelitian ini antara lain: seperangkat alat HPLC (Agilent 1260 Infinity Binary LC) yang dilengkapi dengan detektor DAD, utosampler, dan kolom Zorbax Eclipse Plus C18 (3,5 m; 2,1 x 100 mm), Spektrofotometer UV-Vis PerkinElmer Lambda 25, rotavapor, sonikator, neraca analitik, penyaring vakum beserta saringan berpori 0,4 0,45 $\mu \mathrm{m}$, blender, corong pisah dengan tutup, penangas air, pompa vakum, dan alat gelas yang lazim.

Bahan-bahan yang digunakan antara lain sampel buah tomat, cabai rawit, dan wortel yang diambil dari Pasar Bersehati Tomohon, Pasar Karombasan Manado, dan Pasar Kawangkoan Minahasa, Klorpirifos (Kemurnian $\geq 99,9 \%$, Merck), Asetonitril (gradient grade, $\geq 99,9 \%$, Merck), etilasetat, $\mathrm{Na}_{2} \mathrm{SO}_{4}$ anhidrat, aquabidest.

\section{Prosedur Penelitian}

Secara garis besar, prosedur penelitian ini dibagi menjadi beberapa tahap, yaitu: 
1. Penentuan panjang gelombang serapan maksimum klorpirifos

Panjang gelombang serapan maksimum klorpirifos ditentukan dengan mengukur serapan larutan baku klorpirifos 10 ppm menggunakan spektrofotometer UV/Vis Lambda 25.

\section{Penentuan kondisi optimum HPLC}

Kondisi optimum HPLC ditentukan menggunakan kolom Zorbax Eclipse Plus C18 $(3,5 \mu \mathrm{m} ; 2,1 \times 100 \mathrm{~mm})$ menggunakan detektor DAD pada panjang gelombang $289 \mathrm{~nm}$. Penentuan kondisi optimum HPLC meliputi:

\section{a. Penentuan Komposisi Fasa Gerak}

Fasa gerak yang digunakan dalam penelitian ini adalah air dan asetonitril dengan komposisi air : asetonitril divariasikan dari 100:0; 90:10; 80:20; 70:30; 60:40; 50:50; 40:60; 30:70; 20:80, 10:90, dan $0: 100$. Sebanyak $5 \mu \mathrm{L}$ larutan baku klorpirifos 2 ppm diinjeksikan ke dalam kolom HPLC kemudian ditentukan waktu retensi dan luas area puncak kromatogram masing-masing komposisi fasa gerak tersebut.

\section{b. Penentuan Laju Alir Fasa Gerak}

Laju alir fasa gerak dipalajari dengan mengukur waktu retensi dan luas area puncak kromatogram larutan baku klorpirifos 2 ppm pada laju alir yang divariasikan dari 0,3 - 0,9 $\mathrm{mL} /$ menit menggunakan komposisi fasa gerak optimum yang telah ditentukan sebelumnya.

\section{c. Penentuan Volume Injeksi}

Volume injeksi sampel dipelajari dengan mengukur luas area puncak kromatogram larutan baku klorpirifos 2 ppm dengan volume injeksi divariasikan dari $5-30 \mu \mathrm{L}$ menggunakan komposisi dan laju alir fasa gerak optimum yang telah ditentukan sebelumnya.

\section{Penentuan Kinerja Analitik}

Setelah ditentukan kondisi optimum HPLC, selanjutnya ditentukan kinerja analitik yang meliputi:

\section{a. Presisi}

Presisi ditetapkan berdasarkan keterulangan (repeatability) yang ditentukan dengan mengukur luas area puncak kromatogram larutan baku klorpirifos 2 ppm pada kondisi optimum HPLC. Pengukuran diulangi sebanyak 7 kali kemudian ditentukan simpangan baku relatif (SBR) atau keoefisien variasi $(\mathrm{KV})$.

\section{b. Linearitas dan Kurva kalibrasi}

Kurva kalibrasi dibuat dengan mengukur luas area puncak kromatogram larutan baku klorpirifos dengan konsentrasi yang divariasikan dari 0 - 10 ppm menggunakan kondisi optimum HPLC yang telah ditentukan sebelumnya. Kemudian dibuat kurva kalibrasi dengan mengalurkan luas area puncak kromatogram (sebagai sumbu-y) terhadap konsentrasi larutan baku klorpirifos (sebagai sumbu-x), lalu dihitung persamaan garis regresi dan koefisien korelasinya.

\section{c. Batas Deteksi dan Batas Kuntitasi}

Dalam penelitian ini, nilai batas deteksi (LOD) dan batas kuantitasi (LOQ) dihitung secara statistik melalui garis regresi dari kurva kalibrasi [8]. Nilai LOD dihitung menggunakan persamaan:

$$
L O D=\frac{3 S_{(y / x)}}{b}
$$

Sedangkan nilai LOQ dihitung menggunakan persamaan:

$$
L O Q=\frac{10 s_{(y / x)}}{b}
$$

Dimana $S_{(y / x)}$ adalah simpangan baku residual, dan $b$ adalah slope dari persamaan garis regresi linier.

\section{Hasil dan Pembahasan}

\section{Panjang Gelombang Serapan Maksimum Klorpirifos}

Panjang gelombang serapan maksimum klorpirifos ditentukan dengan mengukur serapan larutan baku klorpirifos $10 \mathrm{mg} / \mathrm{L}$ menggunakan spektrofotometer UV/Vis Lambda 25 pada rentang panjang gelombang $190-700 \mathrm{~nm}$. Berdasarkan hasil pengukuran diperoleh panjang 
gelombang serapan maksimum klorpirifos adalah $\lambda=289 \mathrm{~nm}$ (Gambar 1).

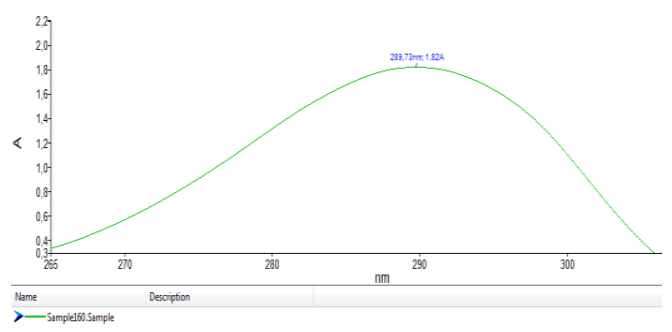

Gambar 1. Panjang gelombang serapan klorpirifos

\section{Penentuan Kondisi Optimum HPLC}

\section{a. Pengaruh Komposisi Fasa gerak}

Fasa gerak yang digunakan dalam penelitian ini adalah air dan asetonitril yang bersifat lebih polar dibandingkan fasa diam, yakni C18 yang bersifat nonpolar. Komposisi fasa gerak optimum ditentukan berdasarkan luas area puncak kromatogram dan waktu retensi, karena luas puncak merupakan parameter yang lebih akurat untuk pengukuran kuantitatif [9].

Hasil pengukuran pada berbagai komposisi fasa gerak air:asetonitril diperlihatkan dalam Tabel 1.

Tabel 1. Pengaruh komposisi air:asetonitril terhadap waktu retensi dan luas area

\begin{tabular}{ccc}
\hline $\begin{array}{c}\text { Komposisi } \\
\text { Air:Asetonitril }\end{array}$ & $\begin{array}{c}\text { Waktu } \\
\text { Retensi } \\
\text { (menit) }\end{array}$ & $\begin{array}{c}\text { Luas Area } \\
\text { (mAU*s) }\end{array}$ \\
\hline $50: 50$ & 6,877 & 1753,36926 \\
$40: 60$ & 6,724 & 32,82681 \\
$30: 70$ & 3,055 & 32,73163 \\
$20: 80$ & 1,797 & 32,44448 \\
$10: 90$ & 1,184 & 32,23305 \\
$0: 100$ & 0,999 & 32,98140 \\
\hline
\end{tabular}

Berdasarkan data pada Tabel 1 dapat dilihat bahwa jika komposisi astonitril diperbesar, maka luas area puncak kromatogram klorpirifos semakin berkurang namun waktu retensinya semakin singkat. Luas area puncak kromatogram klorpirifos terbesar terbaca pada komposisi air:asetonitril (50:50), namun waktu retensinya lebih lama dan kromatogram yang dihasilkan tidak simetris. Oleh karena itu, komposisi fasa gerak air : asetonitril yang digunakan dalam penelitian ini adalah 10 : 90, karena waktu pengukurannya lebih singkat dan luas area puncak kromatogramnya masih cukup baik.

\section{b. Pengaruh Laju Alir Fasa Gerak}

Pengukuran laju alir fasa gerak dilakukan menggunakan komposisi fasa gerak optimum yang telah ditentukan sebelumnya, yaitu pada perbandingan air : asetonitril 10 : 90. Hasil pengkuran tersebut ditunjukkan dalam Tabel 2 berikut.

Tabel 2. Pengaruh Laju Alir Fasa Gerak terhadap Waktu Retensi dan Luas Area

\begin{tabular}{ccc}
\hline $\begin{array}{c}\text { Laju Alir Fasa } \\
\text { Gerak } \\
\text { (mL/menit) }\end{array}$ & $\begin{array}{c}\text { Waktu } \\
\text { Retensi } \\
\text { (menit) }\end{array}$ & $\begin{array}{c}\text { Luas Area } \\
\text { (mAU*s) }\end{array}$ \\
\hline 0,30 & 1,682 & 162,69608 \\
0,50 & 1,006 & 97,39092 \\
0,70 & 0,720 & 72,81155 \\
0,90 & 0,561 & 61,86494 \\
\hline
\end{tabular}

Berdasarkan data pada Tabel 2, dapat dilihat bahwa semakin tinggi laju alir fasa gerak, semakin singkat waktu retensi dan semakin kecil luas area puncak kromatogram yang dihasilkan. Kromatogram terbaik dengan waktu retensi lebih singkat diperoleh pada laju alir 0,70 mL/menit (Gambar 2). Pada laju alir 0,90 mL/menit, kromatogram yang dihasilkan tidak simetris lagi.

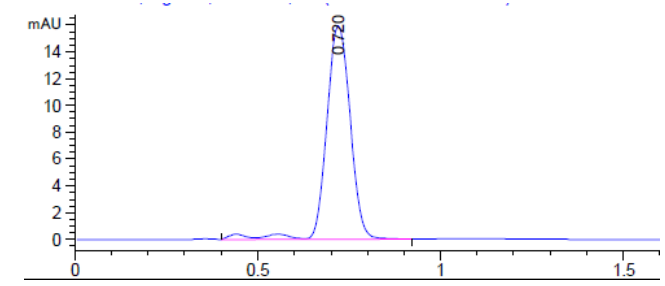

Gambar 2. Kromatogram klorpirifos pada laju alir fasa gerak $0,70 \mathrm{~mL} / \mathrm{menit}$

c. Pengaruh Volume Injeksi Sampel

Pengukuran parameter volume injeksi sampel dilakukan menggunakan komposisi dan laju alir fasa gerak optimum yang telah ditentukan sebelumnya, yaitu komposisi air : asetonitril 10:90 dan laju alir 0,70 mL/menit. Hasil pengkuran tersebut ditunjukkan dalam Tabel 3 berikut.

Tabel 3. Pengaruh Volume Injeksi Sampel terhadap Waktu Retensi dan Luas Area

Volume Waktu Luas Area




\begin{tabular}{ccc}
\hline $\begin{array}{c}\text { Injeksi } \\
\text { Sampel }(\boldsymbol{\mu L})\end{array}$ & $\begin{array}{c}\text { Retensi } \\
\text { (menit) }\end{array}$ & $\left.\mathbf{( m A U}^{*} \mathbf{s}\right)$ \\
\hline 5,0 & 1,184 & 32,23305 \\
10,0 & 1,008 & 65,02857 \\
15,0 & 1,008 & 97,40105 \\
20,0 & 1,004 & 129,75168 \\
25,0 & 1,001 & 178,27931 \\
30,0 & 0,993 & 210,57770 \\
\hline
\end{tabular}

Berdasarkan data pada Tabel 3 dapat dilihat bahwa luas area puncak kromatogram larutan standar klorpirifos semakin besar jika volume injeksi sampel diperbesar, namun pada volume injeksi $\geq 20 \mu \mathrm{L}$, kromatogram larutan baku klorpirifos menjadi tidak simetri lagi. Oleh karena itu, dalam penelitian ini digunakan volume injeksi sampel $15 \mu \mathrm{L}$, karena menghasilkan kromatogram yang lebih baik.

Berdasarkan hasil otimasi parameterparameter kromatografik di atas, maka dapat diringkaskan kondisi optimum HPLC untuk penetapan residu klorpirifos seperti ditunjukkan dalam Tabel 4 berikut.

Tabel 4. Kondisi optimum HPLC untuk penentuan klorpirifos

\begin{tabular}{ll}
\hline \multicolumn{1}{c}{ Parameter } & \multicolumn{1}{c}{ Hasil Pengukuran } \\
\hline Kolom & Zorbax Eclipse Plus C18 \\
& $(3,5 \mu \mathrm{m} ; 2,1 \times 100 \mathrm{~mm})$ \\
Detector & DAD \\
Panjang gelombang & $289 \mathrm{~nm}$ \\
Komposisi fasa gerak & Air : Asetonitril $(10: 90)$ \\
Laju alir fasa gerak & $0,70 \mathrm{~mL} /$ menit \\
Volume injeksi sampel & $15 \mu \mathrm{L}$ \\
\hline
\end{tabular}

\section{Penentuan Kinerja Analitik}

\section{a. Presisi}

Presisi merupakan ukuran yang menunjukkan derajat kesesuaian antara hasil uji individual, diukur melalui penyebaran hasil individual dari rata-rata jika prosedur diterapkan secara berulang pada sampel-sampel yang diambil dari campuran yang homogen [8]. Pada penelitian ini, presisi ditetapkan berdasarkan keterulangan luas area kromatogram hasil analisa dengan 7 kali pengulangan pada larutan standar. Kriteria presisi diberikan jika metode memberikan simpangan baku relatif (RSD) atau koefisien variasi (CV) $2 \%$ atau kurang [8]. Hasil pengukuran ditunjukkan dalam Tabel 5 .

Tabel 5. Penentuan Keterulangan

\begin{tabular}{cc}
\hline Pengukuran ke- & Luas Area \\
\hline 1 & 138,33823 \\
2 & 139,04747 \\
3 & 138,96838 \\
4 & 138,69792 \\
5 & 139,07574 \\
6 & 139,10226 \\
7 & 138,62209 \\
\hline Rerata & 138,83601 \\
Simpangan Baku (SB) & 0,28960094 \\
Koefisien Variasi (KV) & $0,20859209 \%$ \\
\hline
\end{tabular}

Berdasarkan hasil penenlitian seperti yang ditunjukkan dalam Tabel 5, dapat dilihat bahwa nilai koefisien variasi $(\mathrm{KV})$ untuk penentuan klorpirifos 2 ppm adalah 0,2086\%. Karena nilai KV lebih kecil dari 2\% maka metode analisis tersebut mempunyai presisi yang baik [8]. Dengan demikian dapat disimpulkan bahwa sistem operasional alat dan analisis memiliki nilai keterulangan yang baik terhadap metode dengan respon yang relatif konstan, sehingga hasil pengukuran memiliki nilai presisi yang memenuhi persyaratan.

\section{b. Linearitas dan Kurva Kalibrasi}

Linearitas adalah kemampuan metode analisis memberikan respon proporsional terhadap konsentrasi analit dalam sampel [10]. Linearitas biasanya dinyatakan dalam istilah variansi sekitar arah garis regresi yang dihitung berdasarkan persamaan matematik data yang diperoleh dari hasil uji analit dalam sampel dengan berbagai konsentrasi analit [8]. Sebagai parameter adanya hubungan linier digunakan koefisien korelasi $r$ pada analisis regresi linier $y=$ $a+b x$. Hubungan linier ideal dicapai jika nilai $a=0$ dan $r=+1$ atau -1 , bergantung pada arah garis [10].

Berdasarkan hasil pengkuran 5 seri larutan satndar klorpirifos dengan rentang konsentrasi 2 - 10 ppm, didapatkan kurva kalibrasi dengan persamaan garis regresi $y=27,6 x+23,391$ dan nilai koefisien korelasi $R^{2}=0,9963$ seperti ditunjukkan dalam Gambar 3. 


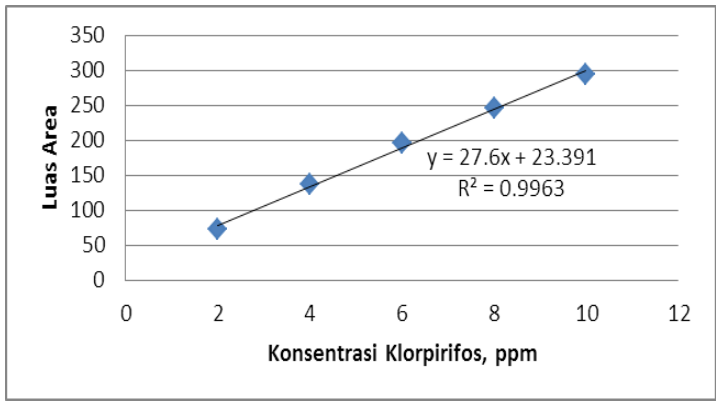

Gambar 3. Kurva kalibrasi Larutan Standar Klorpirifos

Nilai regresi yang baik adalah $\mathrm{R}^{2}>0,99$ [4][8]. Dengan demikian, nilai koefisien korelasi yang diperoleh telah memenuhi persyaratan untuk digunakan dalam pengukuran analisis rutin.

\section{c. Batas Deteksi dan Batas Kuantitasi}

Batas deteksi (LOD) adalah jumlah terkecil analit dalam sampel yang dapat dideteksi yang masih memberikan respon signifikan dibandingkan dengan blangko, sedangkan batas kuantitasi (LOQ) merupakan parameter pada analisis renik dan diartikan sebagai kuantitas terkecil analit dalam sampel yang masih dapat memenuhi kriteria cermat dan seksama [8]. Nilai LOD dan LOQ dihitung secara statistik melalui garis regresi dari kurva kalibrasi.

Berdasarkan hasil penelitian yang dilakukan untuk penentuan klorpirifos dengan metode HPLC, diperoleh nilai LOD sebesar 0,67 ppm dan nilai LOQ sebesar 2,24 ppm. Batas deteksi berguna dalam memastikan suatu respon yang ditimbulkan suatu analisis [11].

\section{Penetapan Kadar Klorpirifos dalam Sampel}

Tujuan penelitian ini adalah untuk menentukan konsentrasi klorpirifos dalam sampel buah tomat, cabai rawit, dan wortel dengan menggunakan HPLC yang telah dioptimasi dan divalidasi sebelumnya [7]. Hasil pengukuran dan perhitungan kadar klorpirifos dalam sampel buah tomat, cabai rawit, dan wortel yang dianalisis dari beberapa pasar tradisional di Sulawesi Utara diringkaskan pada Tabel 6.

Table 6. Konsentrasi Klorpirifos dalam Tomat, Cabai Rawit, dan Wortel yang diambil dari Beberapa Pasar Tradisional di Sulawesi Utara

\begin{tabular}{|c|c|c|c|c|}
\hline No & $\begin{array}{c}\text { Nama } \\
\text { Sampel }\end{array}$ & $\begin{array}{c}\text { Lokasi } \\
\text { Sampling }\end{array}$ & Perlakuan & $\begin{array}{c}\text { [Klorpirifos] } \\
(\mathrm{mg} / \mathrm{kg})\end{array}$ \\
\hline \multirow{6}{*}{1} & \multirow{6}{*}{ Tomat } & \multirow{2}{*}{$\begin{array}{l}\text { Pasar } \\
\text { Bersehati } \\
\text { Tomohon } \\
\end{array}$} & Dicuci & 0.0314 \\
\hline & & & $\begin{array}{l}\text { Tidak } \\
\text { Dicuci }\end{array}$ & 0.0471 \\
\hline & & \multirow{2}{*}{$\begin{array}{l}\text { Pasar } \\
\text { Karombasan } \\
\text { Manado }\end{array}$} & Dicuci & 0.0146 \\
\hline & & & $\begin{array}{l}\text { Tidak } \\
\text { Dicuci }\end{array}$ & 0.0594 \\
\hline & & \multirow{2}{*}{$\begin{array}{l}\text { Pasar } \\
\text { Kawangkoan }\end{array}$} & Dicuci & $\begin{array}{c}\text { Tidak } \\
\text { Terdeteksi }\end{array}$ \\
\hline & & & $\begin{array}{c}\text { Tidak } \\
\text { Dicuci }\end{array}$ & 0.3150 \\
\hline \multirow{6}{*}{2} & \multirow{6}{*}{$\begin{array}{l}\text { Cabai } \\
\text { Rawit }\end{array}$} & \multirow{2}{*}{$\begin{array}{l}\text { Pasar } \\
\text { Bersehati } \\
\text { Tomohon } \\
\end{array}$} & Dicuci & 0.1459 \\
\hline & & & $\begin{array}{l}\text { Tidak } \\
\text { Dicuci }\end{array}$ & 0.1875 \\
\hline & & \multirow{2}{*}{$\begin{array}{l}\text { Pasar } \\
\text { Karombasan } \\
\text { Manado }\end{array}$} & Dicuci & 0.1397 \\
\hline & & & $\begin{array}{l}\text { Tidak } \\
\text { Dicuci }\end{array}$ & 0.1502 \\
\hline & & \multirow{2}{*}{$\begin{array}{l}\text { Pasar } \\
\text { Kawangkoan }\end{array}$} & Dicuci & $\begin{array}{c}\text { Tidak } \\
\text { Terdeteksi } \\
\end{array}$ \\
\hline & & & $\begin{array}{c}\text { Tidak } \\
\text { Dicuci }\end{array}$ & $\begin{array}{c}\text { Tidak } \\
\text { Terdeteksi }\end{array}$ \\
\hline \multirow{6}{*}{3} & \multirow{6}{*}{ Wortel } & \multirow{2}{*}{$\begin{array}{l}\text { Pasar } \\
\text { Bersehati } \\
\text { Tomohon } \\
\end{array}$} & Dicuci & 0.0105 \\
\hline & & & $\begin{array}{l}\text { Tidak } \\
\text { Dicuci }\end{array}$ & 0.0304 \\
\hline & & \multirow{2}{*}{$\begin{array}{l}\text { Pasar } \\
\text { Karombasan } \\
\text { Manado }\end{array}$} & Dicuci & -0.0003 \\
\hline & & & $\begin{array}{l}\text { Tidak } \\
\text { Dicuci }\end{array}$ & 0.0034 \\
\hline & & \multirow{2}{*}{$\begin{array}{l}\text { Pasar } \\
\text { Kawangkoan }\end{array}$} & Dicuci & 0.0040 \\
\hline & & & $\begin{array}{c}\text { Tidak } \\
\text { Dicuci }\end{array}$ & 0.0049 \\
\hline
\end{tabular}

Berdasarkan data pada Tabel 6, dapat dilihat bahwa pestisida dengan bahan aktif klorpirifos terdeteksi hampir pada semua sampel yang dianalisis, walaupun kadarnya masih berada di bawah nilai BMR yang ditetapkan, yaitu $1 \mathrm{mg} / \mathrm{kg}$. kadar klorpirifos tertinggi dijumpai pada sampel buah tomat yang berasal dari pasar Kawangkoan Minahasa, yaitu sebesar $0,3150 \mathrm{mg} / \mathrm{kg}$ sampel. Hasil penelitian ini juga memperlihatkan bahwa sampel yang dicuci terlebih dahulu sebelum diekstraksi dapat menurunkan kadar pestisidanya. Hasil penelitian ini diharapkan dapat menjadi bahan pertimbangan bagi instansi terkait yang ada di Sulawesi Utara agar lebih sering memonitor dan mengevaluasi tentang keberadaan dan penggunaan pestisida.

\section{Ucapan Terimakasih}

Terima kasih disampaikan kepada Direktorat Riset dan Pengabdian kepada Masyarakat (DRPM) Kementrian Riset, Teknologi 
dan Pendidikan Tinggi, yang telah mendanai penelitian ini melalui skema Penelitian Dosen Pemula (PDP).

\section{Kesimpulan}

Berdasarkan hasil yang telah dicapai dalam penelitian ini, maka dapat disimpulkan bahwa metode HPLC yang telah dioptimasi dan divalidasi dapat digunakan untuk menentukan kadar residu klorpirifos dalam sampel buah tomat, cabai rawit, dan wortel dengan ketelitian yang tinggi, sehingga dapat juga digunakan untuk analisis rutin senyawa klorpirifos dalam berbagai sampel.

\section{Daftar Pustaka}

1. Saiya, A., Gumolung, D., dan Howan, D.H.O. Analisis Residu Klorpirifos dalam Sayuran Kubis dengan Metode HPLC di Beberapa Pasar Tradisional di Sulawesi Utara. EKSATA: Berkala Ilmiah Bidang MIPA Universitas Negeri Padang. 2017.18 (2): 77 - 85

2. Chen, C., Qian, Y., Chen, Q., Tao, C., Li, C., dan $\mathrm{Li}, \mathrm{Y}$. Evaluation of pesticide residues in fruits and vegetables from Xiamen, China. Food Control. 2011. 22 (7): 1114-1120.

3. Yao, Z.W., Jiang, G.B., Liu, J.M., Cheng, W. Application of solid-phase microextraction for the determination of organophosphorus pesticides in aqueous sample by gas chromatography with flame photometric detector. Talanta. 2001. 55 (4): 807 - 814

4. Panggabean, A.S. Analisis Residu Klorpirifos dalam Sayur-Sayuran dengan Teknik High Performance Liquid Chromatography (HPLC). Jurnal Kimia Mulawarman. 2016. 13 (2): 57-63.

5. Marzuki, A., Naid, T., dan Risky. Analisis Residu Klorpirifos Pada Sawi Hijau (Brassica Rapa Var.Parachinensis L.) Terhadap Parameter Waktu Retensi Metode Kromatografi Gas. PHARMACON: Jurnal Ilmiah Farmasi UNSRAT. 2014. 3(4): 133 - 143

6. Triani, I.G.A.L., Gunam, I.B.W., dan Wrasiati. Analisis Residu Insektisida pada Kacang Panjang (Vigna sinensis) yang Dihasilkan di Kabupaten Tabanan. Laporan Akhir Penelitian Hibah Bersaing, 2013. Universitas Udayana, Denpasar.
7. Saiya, A., Gumolung, D., dan Howan, D.H.O. Optimasi dan Validasi Metode Analisis Residu Klorpirifos Menggunakan High Performance Liquid Chromatography (HPLC). Fullerene Journ. of Chem. 2017. 2 (2): $103-109$

8. Harmita. Review Artikel: Petunjuk Pelaksanaan Validasi Metode dan Cara Perhitungannya. Majalah Ilmu Kefarmasian. 2004. 1 (3): 117-135.

9. Panggabean, A. S., Amran, M.B., Buchari dan Achmad, S. Speciation of Organotin Compounds with Ion Pair- Reversed Phase Chromatography Technique. Eurasian Journal of Analytical Chemistry. 2009. 4 (2): 215-225

10. Riyanto. Validasi \& Verifikasi Metode Uji: Sesuai dengan ISO/IEC 17025 Laboratorium Pengujian dan Kalibrasi. 2014. Penerbit Deepuplish. Yogyakarta.

11. Panggabean, A.S., Subur P. Pasaribu, Bohari, dan Nurhasanah. Preconcentration of Chromium(VI) at Trace Levels Using Acid Alumina Resin With Column Method. Indo. J. of Chem. 2014. 14 (1): 51-56 